\title{
Insect populations of six dryland pastures grown in Canterbury
}

\author{
N.J. MORRIS ${ }^{1}$, M.C. SMITH ${ }^{2}$, A.M. MILLS ${ }^{2}$, M.R. McNEILL ${ }^{3}$ and D.J. MOOT ${ }^{2}$ \\ 1431 Taverners Road, RD2, Ashburton 7772, New Zealand \\ ${ }^{2}$ Field Research Centre, Faculty of Agriculture \& Life Sciences, PO Box 85084, \\ Lincoln University, Lincoln 7674, New Zealand \\ ${ }^{3}$ AgResearch Lincoln, Private Bag 4749, Christchurch 8140, New Zealand \\ nicolejanemorris@gmail.com
}

\begin{abstract}
The 9 year 'MaxClover' experiment at Lincoln University concluded that ryegrass and white clover pastures were less persistent than cocksfoot and lucerne under dryland conditions in Canterbury. Measurements of insect pests commenced in Year 5 in response to a measured decline in sown ryegrass and white clover. The aim was to determine if there were differences in insect pressure among the different pastures. Insect pest pressure was present in all pastures from when measurements commenced until the experiment finished in Year 9. Grass grub larvae were the main pest that contributed to the decline in sown species, particularly in ryegrass/white clover, and they were found in all grass-based pasture treatments. Larval populations reached $156 / \mathrm{m}^{2}$ in August 2008 in the cocksfoot/balansa clover and cocksfoot/white clover pastures. Argentine stem weevil overwintering adult populations reached $63 / \mathrm{m}^{2}$ in July 2010 and were highest in cocksfoot/Subterranean clover pastures. These may have contributed to the slow decline in cocksfoot. Low populations $\left(<5 / \mathrm{m}^{2}\right)$ of adult clover root weevil were found in all treatments in winter 2010, with dissection finding reproductively mature adults with no indication of parasitism by Microctonus aethiopoides. Lucerne was the only host of Sitona discoideus. Results suggest insect pressure did not differ among the grassbased pastures over the duration of measurements but white clover appears to have been the main host for grass grub.
\end{abstract}

Keywords: 'MaxClover', botanical composition, Listronotus bonariensis (Kuschel), Sitona obsoletus, Sitona discoideus, Costelytra zealandica, Aphodius tasmaniae, Wiseana cervinata

\section{Introduction}

Eastern regions of the North and South Islands of New Zealand experience water deficits in summer in most years (Brown \& Green 2003); these can impose a severe limitation on the productivity and sustainability of pastoral farms in these regions. The most common pasture used in New Zealand is a mixture of perennial ryegrass (Lolium perenne) and white clover (Trifolium repens). These species are suited to summer moist environments and moderate to high soil fertility (Brock et al. 2003). However, their persistence is shorter in dryland regions where annual rainfall is $<750 \mathrm{~mm}$ (Knowles et al. 2003).

Insect pest pressure can affect the productivity and persistence of pastures, particularly when coupled with water stress. The major pasture insect pests in the South Island are grass grub (Costelytra zealandica) and porina (Wiseana spp.), both native species, and the exotic Argentine stem weevil (Listronotus bonariensis (Kuschel)) and clover root weevil (Sitona obsoletus) (Phillips et al. 2007). The larval stages of these insects can cause chronic and acute yield losses in pasture, with damage thresholds dependent on both biotic and abiotic factors (Zydenbos et al. 2011). In dryland pastures, the impact of insects on pasture persistence and productivity can often occur at lower insect populations than when irrigated (e.g. Jackson \& Townsend 1991; McNeill et al. 2003). This is because sown species are unable to compensate for insect related plant biomass loss in the face of herbivore grazing and moisture stress. Conversely, pastures that are persistent in dryland conditions may engender lower populations of insect pests or have greater damage tolerance at the same level of infestation.

Grass grub larvae damage pastures by feeding on roots of grasses and clover and damage occurs in dryland pastures when grass grub larvae populations reach $150 / \mathrm{m}^{2}$ (Barratt et al. 1990). Peak populations occur between 2-6 years after sowing new pasture (Fraser 1994; Jackson 1990) then numbers decline naturally to lower levels over 2-3 years (East \& Kain 1982). The decline is related to a build-up of naturally occurring diseases that kill the grubs (Zydenbos et al. 2011). Further damage to long-term yield and quality of pastures occurs following grass grub attack related to ongoing infestations and weed ingress.

Porina larvae feed on ryegrass, white clover and other pasture plants, hiding in burrows during the day to emerge under the cover of darkness to feed on the foliage at ground level. Damage tends to occur 1-4 years after cultivation in newer pastures but after a drought event pastures of any age may be affected. Production losses start to occur with between 25-50 porina larvae/ $\mathrm{m}^{2}$ (Barratt et al. 1990), and pasture composition will 
change when 50-75 larvae $/ \mathrm{m}^{2}$ are present. When levels are $>100$ larvae $/ \mathrm{m}^{2}$, major pasture damage occurs.

Clover root weevil (CRW) has been a serious pest of white clover in dryland and irrigated pastures since its discovery in Waikato in 1996 (Gerard et al. 2009) and Canterbury in January 2006 (Phillips et al. 2007). White clover is highly susceptible to damage, particularly when under moisture stress (Crush et al. 2008). In addition, dry conditions can have a detrimental impact on CRW egg survival (Eerens \& Hardwick 2003). Adults are found almost all year round, with mature female CRW laying eggs from summer through to spring. There are two larval generations/year in the Canterbury region of New Zealand, with the first and largest peak occurring in October-November (spring), and a second smaller peak occurring in April-May (autumn) (M. R. McNeill unpubl. data). Adult and larval populations of around $300 / \mathrm{m}^{2}$ can reduce clover DM (dry matter) production by $35 \%$ in spring (Gerard et al. 2007).

Argentine stem weevil (ASW) attacks a range of grass species although ryegrass is a preferred species (Goldson 1982). There are two generations/year, with adults undergoing an overwintering reproductive diapause. First generation egg laying commences in September and peaks in late October-early November with second generation egg laying peaking in early February (Goldson et al. 2011). Under optimal conditions, a female ASW can lay between 150 (Kalvelage 1999) to 300 eggs in her lifetime (Malone 1987), with one larvae able to destroy up to eight ryegrass tillers during its development (Barker et al. 1989). Control in ryegrass has mainly relied on endophyte which can deter adult feeding and egg laying or larval development depending on the strain. To complement the role of endophyte, a biological control programme saw the widespread release of the parasitoid wasp Microctonus hyperodae in the 1990s (McNeill et al. 2002). However, parasitoid effectiveness has declined from mid-2000 (Goldson et al. 2014).

Two other forage pests are common in Canterbury. Tasmanian grass grub (Aphodius tasmaniae) larvae graze foliage aboveground nocturnally and production of established pastures can be reduced by $8 \%$ if 100 larvae $/ \mathrm{m}^{2}$ are present (Slay $\&$ Brock 2002). The lucerne weevil (Sitona discoideus) has been an economically damaging pest of lucerne in New Zealand (Goldson et al. 1985, 1987) but currently appears to be kept in check by its biological control agent Microctonus aethiopoides (Moroccan ecotype) (Goldson et al. 1990).

The insect assessments described in this paper occurred within the 'MaxClover' dryland grazing experiment (Mills et al. 2015). In this experiment, sown species declined in the perennial ryegrass/white clover pasture by $\sim 10 \%$ per annum compared with $4 \%$ per annum for cocksfoot-based pastures (Moot 2014). The insect sampling commenced in response to a measured decline in sown species, particuarly in Year 4, of the perennial ryegrass and white clover pastures. This paper reports on the autumn and winter pest populations in the 'MaxClover' pastures to determine whether they may have contributed to differences in pasture persistence. Grass grub and porina were sampled annually over 5 years (2008-2012) and intensive monitoring of several species was undertaken in 2010.

\section{Methods \\ Background}

Details on the 'MaxClover' experimental site and design, climate, pasture and grazing management were described by Mills et al. (2015). In summary, 9 years of animal and pasture data were collected at Lincoln University, Canterbury, New Zealand $\left(43^{\circ} 38^{\prime} \mathrm{S}\right.$, $172^{\circ} 28^{\prime} \mathrm{E}, 11 \mathrm{~m}$ a.s.l) from 2002-2012. The experiment compared six pastures in a randomised complete block design with six replicates. Each plot was 0.05 ha (23 $\times 22 \mathrm{~m}$ ) and individual plots were fenced so animals were grazed on the same pasture type. The pastures were cocksfoot (Dactylis glomerata) (CF) established with subterranean (Trifolium subterraneum) (CF/Sub), balansa (Trifolium michaelianum) (CF/Bal), white $(\mathrm{CF} / \mathrm{Wc})$ or Caucasian (Trifolium ambiguum) $(\mathrm{CF} / \mathrm{Cc})$ clovers, compared with an AR1 perennial ryegrass/ white clover $(\mathrm{RG} / \mathrm{Wc})$ control and a lucerne (Medicago sativa) (Luc) monoculture.

\section{Insect populations}

Belowground larval pest populations were sampled each winter over 5 years (2008-2012) using 20 core samples $(7 \mathrm{~cm}$ diameter by $10 \mathrm{~cm}$ deep) from each of the six replicates of each pasture. Sampling commenced after a $40 \%$ decline in the sown species component in the RG/Wc plots (Moot 2014). Individual sample dates were spread over July, August and September to fit in with each replicate being grazed. Core samples were taken post-grazing. CRW larval populations were only sampled once in 2010 , with 20 cores $(10 \mathrm{~cm}$ diameter $\mathrm{x} 10 \mathrm{~cm}$ deep) collected between 28 July and 20 September 2010 from each of the four pastures and four replicates, described above. Cores were sorted in the field and larvae were identified and counted. For both $S$. discoideus and CRW, the small first instar larvae were inside nodules, cryptic and difficult to assess accurately. Therefore, larval densities measured were most likely an underestimate of actual populations present.

Adult weevils of ASW, CRW and S. discoideus were sampled on 22 June, 28 July and 15 September 2010 from four pastures (CF/Sub, CF/Wc, RG/Wc and Luc) in four replicates $(1,2,3$ and 6$)$. Fifteen quadrats $(0.2$ $\mathrm{m}^{2}$ ) per plot were vacuumed using a modified blower- 
vac (Echo ES 2400) with a mesh net attached to the intake pipe. Samples were sieved and the weevils collected and counted under a heat lamp. Conditions on each occasion were dry to maximise recovery of insects present within the quadrats. To determine the reproductive status of CRW, weevils were frozen at $-40^{\circ} \mathrm{C}$, then set in a wax plaque and covered with $50 \%$ ethanol. Weevils were then dissected under a binocular scope and scored as being mature if eggs were present in the calyces and if parasitised.

\section{Statistical analysis}

Least squares linear regression and one-way analysis of variance (ANOVA) with means separation using least significant differences were used to analyse the insect population data. Data were analysed as a randomised complete block design using four or six replicates where appropriate. Data collected for insect populations were square root-transformed before analysis when appropriate to account for the non-normal (Poisson) distribution of the data. One-way ANOVA was used to compare treatment means over the individual measurement periods. Insect populations per square metre are used to describe results with $P$ values stated to show statistical difference but error bars presented in graphs are backtransformed and therefore are not always symmetrical.

\section{Results}

Mean ( \pm SEM) grass grub larval populations across the 5 year measurement period showed differences among treatments in August $2008(\mathrm{P}<0.05)$ and September $2009(\mathrm{P}<0.05)$. Larval populations in August 2008 were highest in the $\mathrm{CF} / \mathrm{Bal}$ and $\mathrm{CF} / \mathrm{Wc}$ plots at $156 \pm 23.2$ larvae/ $\mathrm{m}^{2}$ (Figure 1). These were higher than $\mathrm{CF} / \mathrm{Cc}$ $\left(95 \pm 23.2\right.$ larvae $\left./ \mathrm{m}^{2}\right)$, CF Sub $\left(61 \pm 23.2\right.$ larvae $\left./ \mathrm{m}^{2}\right)$ and lucerne $\left(43 \pm 23.2\right.$ larvae $\left./ \mathrm{m}^{2}\right)$. RG/Wc plots had 78 \pm 23.2 larvae $/ \mathrm{m}^{2}$ during this sampling period. Results from the September 2009 sampling showed lucerne pastures had a lower grass grub population $(20 \pm 23.2$ larvae $\left./ \mathrm{m}^{2}\right)$ than $\mathrm{CF} / \mathrm{Wc}$ pastures $(123 \pm 23.2$ larvae/ $\left.\mathrm{m}^{2}\right)$ which had the highest $(\mathrm{P}<0.05)$ population. Larval populations within the other pasture treatments ranged from $26 \pm 23.2 / \mathrm{m}^{2}(\mathrm{CF} / \mathrm{Sub})$ to $72 \pm 23.2 / \mathrm{m}^{2}(\mathrm{RG} / \mathrm{Wc})$. Tasmanian grass grub larval populations began to increase in 2009, peaking 9 years after sowing in July 2011 in all pastures (Figure 2). Lucerne plots had the highest populations compared with other treatments, with means of $56 \pm 12.4 / \mathrm{m}^{2}$ in August $2010(\mathrm{P}<0.05)$, $179 \pm 23.5 / \mathrm{m}^{2}$ in July $2011(\mathrm{P}<0.001)$ and $41 \pm 6.6 / \mathrm{m}^{2}$ in July $2012(\mathrm{P}<0.001)$. Populations for other pastures in August 2010 were less than $24 \pm 12.4 / \mathrm{m}^{2}$. RG/Wc pastures had $70 \pm 23.5$ larvae $/ \mathrm{m}^{2}$ present in the July 2011 sampling period and all other pasture treatments 


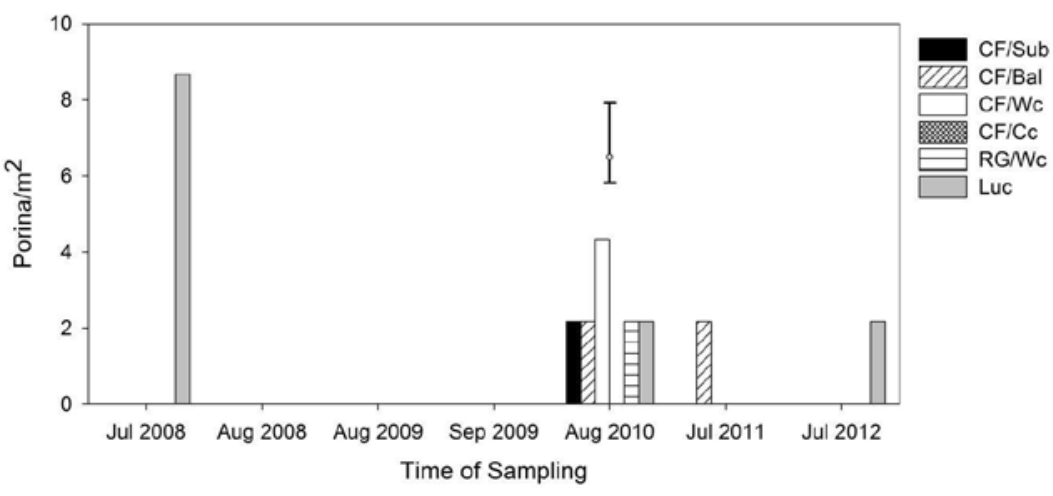

Figure 3 Number of porina larvae $\left(/ \mathrm{m}^{2}\right)$ in six dryland pastures quantified at seven times over 5 years (2008-2012) when pastures were 8-11 years old. Porina were absent in 2008 and 2009. Only 1-2 plots had porina present in July 2008, 2011 and 2012, and therefore data were not analysed. Error bars are back-transformed SEM in Aug 2010 as data were left skew. Arithmetic treatment means are presented (bars). Key - see caption to Figure 1.

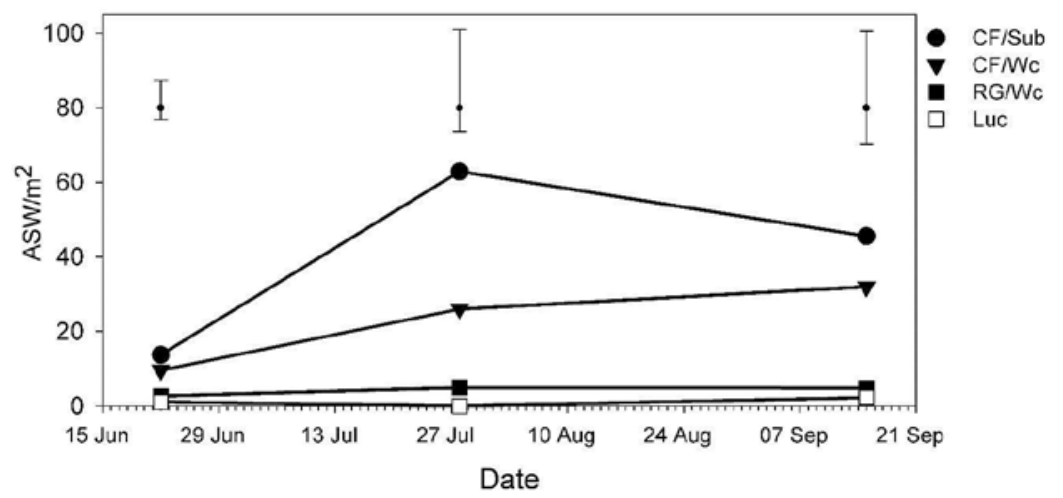

Figure 4 Number of adult Argentine stem weevil (ASW) $\left(/ \mathrm{m}^{2}\right)$ in four dryland pastures quantified three times between June and September 2010 when pastures were 9 years old. Back transformed error bars are SEM's of grand mean for the sampling date. Key - see caption to Figure 1.

had populations between $28 \pm 23.5$ and $52 \pm 23.5 / \mathrm{m}^{2}$.

The presence of Porina caterpillars was highly sporadic. While only present in lucerne in 2008, they were absent in all pastures in 2009 , then present at low levels in all pasture treatments apart from $\mathrm{CF} / \mathrm{Cc}$ pastures in August 2010 (Figure 3).

Sampling for ASW adult populations ( \pm SEM) in June and July of 2010, indicated peak winter populations in July, with $63 \pm 1.0 / \mathrm{m}^{2}$ in $\mathrm{CF} / \mathrm{Sub}$ and $26 \pm 1.0 /$ $\mathrm{m}^{2}$ in $\mathrm{CF} / \mathrm{Wc}$ treatments compared with $6 \pm 1.0 / \mathrm{m}^{2}$ and $2 \pm 1.0 / \mathrm{m}^{2}$ in $\mathrm{RG} / \mathrm{Wc}$ and lucerne, respectively. Differences in density were significant in July $(\mathrm{P}<0.01)$ and September $(\mathrm{P}<0.001)$ (Figure 4). Adult CRW populations were consistently low in all pastures from June to September 2010 (Figure 5). During June, CRW populations $( \pm \mathrm{SEM})$ were higher $(\mathrm{P}<0.01)$ in the $\mathrm{CF} /$ Wc pastures $\left(4 \pm 0.3 / \mathrm{m}^{2}\right)$ and $\mathrm{CF} / \mathrm{Sub}$ pastures $(3 \pm$ $\left.0.3 / \mathrm{m}^{2}\right)$ than in $\mathrm{RG} / \mathrm{Wc}\left(2 \pm 0.3 / \mathrm{m}^{2}\right)$ pastures. CRW larvae sampling in August and September only found larvae $( \pm \mathrm{SEM})$ in $\mathrm{CF} / \mathrm{Wc}$ $\left(4 \pm 4.8 / \mathrm{m}^{2}\right)$ and $\mathrm{RG} / \mathrm{Wc}$ $\left(15 \pm 4.8 / \mathrm{m}^{2}\right)$ pastures, respectively.

Adult S. discoideus were also present, but only within the lucerne plots. Means of $3 \pm 0.20,9 \pm 0.22$ and $5 \pm 0.14$ adult weevils/ $\mathrm{m}^{2}$ were recorded in June, July and September, respectively.

\section{Discussion}

This study was carried out on the 'MaxClover' pastures during years 5-9 (2008-2012) after an observable decline in RG/ Wc in Year 4 (Moot 2014; Mills et al. 2015). The insect numbers present may have contributed to the decline in sown species. By Year 9 (2010/2011), in the CF pastures, over $70 \%$ of the sown species were still present compared with less than $10 \%$ for the $\mathrm{RG} / \mathrm{Wc}$ pastures. Lucerne monocultures were still $85 \%$ pure due to ongoing targeted winter weed control. It is not possible to precisely determine if the pests initiated the decline in sown species. However, the relative abundance of the insect species present does indicate most likely candidates.

Grass grub was the main insect pest and this probably had the greatest impact on botanical composition over time. The environmental conditions surrounding the 'MaxClover' experiment were conducive to high grass grub populations. The free draining Templeton soil and surrounding shelter belts have both been noted as favourable grass grub habitats (Hardwick 2004). As a consequence, insect pressure was likely to be high. When coupled with seasonal drought every summer, this placed all pastures under almost constant biotic and abiotic stresses. This is typical of many dryland farms in summer drought regions. Larvae were present through all grass pastures (Figure 1) and were around the damage threshold levels of 150 larvae $/ \mathrm{m}^{2}$ in the $\mathrm{CF} / \mathrm{Bal}$ and $\mathrm{CF} / \mathrm{Wc}$ pastures when first sampled in 
August 2008 (Figure 1). Given the pastures were sown in 2002, grass grub populations are likely to have been this level or higher before sampling commencing in winter 2008. It is suggested that they contributed to the reported decline in sown species throughout the trial (Mills et al. 2015). Hardwick (2004) states that grass grub will feed on both grass and clover,

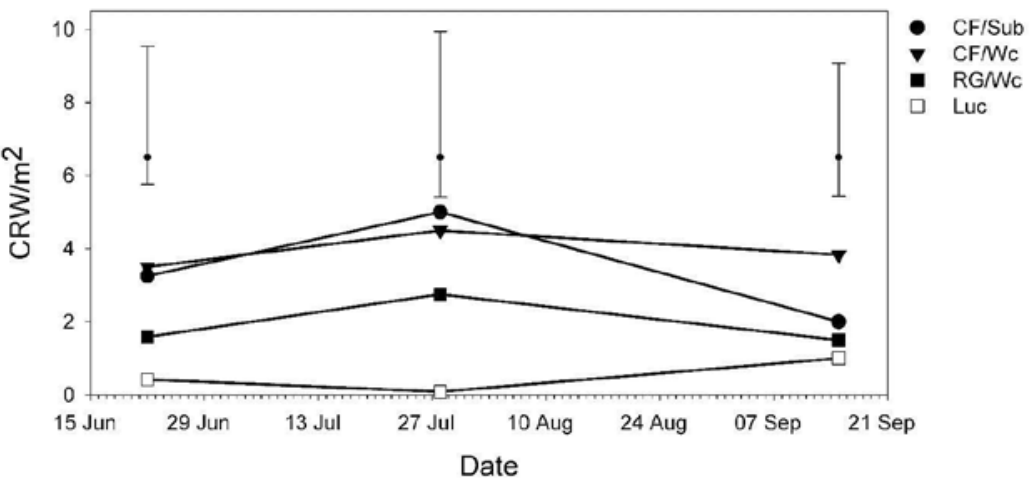

Figure $5 \quad$ Number of adult clover root weevil $\left(\mathrm{CRW} / \mathrm{m}^{2}\right)$ in four dryland pastures quantified three times between June and September 2010 when pastures were 9 years old. Back- transformed error bars are SEM's of grand mean for the sampling date. Key - see caption to Figure 1.

extremely favourable host and is most susceptible to

damage (Radcliffe 1971; Kain \& Atkinson 1977).

In the 'MaxClover' experiment, it seems that grass grub selectively targeted the white clover pastures, with $\mathrm{RG} / \mathrm{Wc}$ and $\mathrm{CF} / \mathrm{Wc}$ plots reaching damaging thresholds at certain stages between 2008 and 2010. The $\mathrm{CF} / \mathrm{Bal}$ may also have reached a damaging population because of the ingress of volunteer white clover (VWC). In 2008/2009, 2009/2010 and 2010/2011, these pastures had annual VWC yields of 679,986 and $389 \mathrm{~kg} / \mathrm{ha}$, respectively (Mills et al. 2015). Whether balansa clover is also a preferred species for grass grub is currently unknown. In the other annual clover combination, $\mathrm{CF} / \mathrm{Sub}$ pastures, grass grub larval populations, were below damaging thresholds and the VWC content was lower with annual yields of 209, 178 and $166 \mathrm{~kg} / \mathrm{ha}$ in 2008/2009, 2009/2010 and 2010/2011, respectively.

$\mathrm{CF} / \mathrm{Cc}$ pastures had the highest yields of VWC throughout the 'MaxClover' experiment with $1291 \mathrm{~kg} /$ ha in 2007/2008. However, it always maintained grass grub populations below threshold levels. Fewer grass grub larvae are generally found under Caucasian clover when compared with white clover (Watson et al. 1996) which confirms the preference for white clover over other clover species. Watson et al. (1997) also stated that Caucasian clover has a higher tolerance for grass grub. Radcliffe (1971) stated that when comparing pasture species, the loss of yield is greater in white clover compared to ryegrass. In this study, the loss of 'sown components' was measured but ryegrass and white clover were not individually separated.

The lucerne monocultures within the 'MaxClover' experiment were never found to have grass grub at damaging thresholds (Figure 1). Grass grub larvae survival and growth rates were lower under lucerne compared to perennial ryegrass (Farrell \& Sweney 1972) and fewer larvae have been found to survive under lucerne than clover. Prestidge et al. (1985) also found similar results in laboratory studies, with ryegrass and white clover being favourable hosts for $3^{\text {rd }}$ instar grass grub larvae and lucerne and cocksfoot being unfavourable hosts. East et al. (1980) found that lucerne suppresses grass grub larvae to low numbers. Grass grub effects on herbage production were less in lucerne and cocksfoot-based pastures compared with ryegrass and white clover pastures which are susceptible. This literature is consistent with the measured data of higher presence of grass grub in white clover than other clovers or lucerne or cocksfoot.

The low Tasmanian grass grub populations in 2008 and 2009 suggest this pest was not a factor in the decline in sown species. The lucerne treatment had a higher population of Tasmanian grass grub (Figure 2) compared with other pastures in $2010(\mathrm{P}<0.05), 2011$ and $2012(\mathrm{P}<0.001)$. This was probably because the aboveground feeding Tasmanian grass grub prefers legumes over grasses (Slay \& Brock 2002) and females prefer the open vegetation, typical of lucerne stands, for oviposition (Watson et al. 1996). The lower Tasmanian grass grub populations in Caucasian than white clover pastures (Figure 2) are also consistent with previous reports (Watson et al. 1996).

Porina populations in these pastures from 20082012 were $<4$ larvae $/ \mathrm{m}^{2}$ (Figure 3 ) and well below damaging thresholds (20-40 larvae $/ \mathrm{m}^{2}$ ), where losses in pasture productivity and invasion of weeds will occur (Zydenbos et al. 2011). Therefore, this insect was not considered to have caused the decline in sown species.

The highest ASW populations were found in cocksfoot plots in July $2010(\mathrm{P}<0.01)$ and in September $2010(\mathrm{P}<0.001)$. The ASW populations do not seem to have been sufficient to cause the primary decline in sown species, particularly in RG/Wc. However, ASW winter populations in cocksfoot did reflect its availability as a favourable species. Cocksfoot is a favourable host, 
compared with ryegrass containing AR1 endophyte; lucerne is not a host species. Cocksfoot is considered a favourable host for larval attack but onwards from $2^{\text {nd }}$ instar, survival rates were lower (Goldson 1979). In addition, by 2010 , ryegrass was contributing less than $10 \%$ of the botanical composition in the RG/Wc pastures while cocksfoot was over $50 \%$ of DM. The ASW populations in cocksfoot were sufficiently high that damage during summer may have contributed to its slow rate of decline over time (Moot 2014). The ryegrass endophyte was tested in 2010 and was still $100 \%$ in the sampled perennial ryegrass tillers ( $R$. Bryant 2012 pers. comm.). This suggests the ryegrass plants within the RG/Wc plots were an unfavourable host for ASW adults.

Clover root weevil adult $\left(2-5 / \mathrm{m}^{2}\right)$ and larval populations were low in 2010, and well below damaging levels. Therefore the CRW adult differences found are not considered biologically meaningful (Figure 5). This contrasts with October 2010 populations of over 400 larvae $/ \mathrm{m}^{2}$ in irrigated pasture at the Lincoln University Research Dairy farm approximately $2 \mathrm{~km}$ away from this experiment site (McNeill 2016 pers. comm.). However, CRW was only detected in Canterbury in 2006 (Phillips et al. 2007), and it is not possible to assess when the species arrived on the site or its role in white clover decline. CRW only feeds on Trifolium species. Volunteer white clover was present in all pastures during summer 2009 (Mills et al. 2015) and this would contribute to CRW being present in the lucerne plots.

The only host present for $S$. discoideus in this experiment was lucerne and populations were low during winter 2010 with $<10 / \mathrm{m}^{2}$. This species is well controlled by the biocontrol agent Microctonus aethiopiodes (Moroccan biotype) (Goldson et al. 1990) and it is most unlikely they impacted on stand persistence.

\section{Conclusions}

Grass grub was the only species at population levels above thresholds reported as being damaging for pastures. While pre-2008 populations are unknown, it appears the $\mathrm{RG} / \mathrm{Wc}$ pastures were less tolerant to grass grub than the cocksfoot under similar levels of insect pressure and abiotic stress. ASW was at sufficiently high populations in CF plots in 2010 to cause long-term decline in these pastures. At the densities recorded it is unlikely that porina and Tasmanian grass grub were contributors to the decline in sown species. The two Sitona spp. were also well below damaging levels in 2010 .

\section{ACKNOWLEDGEMENTS}

The authors acknowledge financial assistance from Beef + Lamb New Zealand through the Pastoral 21 programme. Technical assistance was provided by Malcolm Smith (Lincoln University), pasture agronomy students, and Scott Hardwick (AgResearch, Lincoln). Assistance with statistical analysis was provided by Dr. Anna Mills (Lincoln University). Two anonymous reviewers provided helpful comments.

\section{REFERENCES}

Barker, G.M.; Pottinger, R.P.; Addison, P.J. 1989. Population dynamics of the Argentine stem weevil (Listronotus bonariensis) in pastures of Waikato, New Zealand. Agriculture, Ecosystems \& Environment 26: 79-115.

Barratt, B.I.P.; van Toor, R.F.; Ferguson, C.M.; Stewart, K.M. 1990. Grass grub and porina in Otago and Southland: a guide to management and control. MAF Technology, Invermay Agricultural Centre.

Brock, J.L.; Hyslop, M.G.; Widdup, K.H. 2003. A review of red and white clovers in the dryland environment. Legumes for dryland pastures. Grassland Research and Practice Series 11: 101-107.

Brown, C.D.; Green, R.B. 2003. The challenges facing legumes in a dryland environment - a consultant's view. Legumes for dryland pastures. Grassland Research and Practice Series 11: 7-12.

Crush, J.R.; Gerard, P.J.; Ouyang, L.; Wilson, D.J. 2008. Effect of clover root weevil and moisture stress on subterranean, balansa, Persian, arrowleaf and white clovers. Proceedings of the New Zealand Grassland Association 70: 255-257.

East, R.; Kain, W.M.; Douglas, J.A. 1980. The effect of grass grub on the herbage production of different pasture species in the pumice country. Proceedings of the New Zealand Grassland Association 42: $105-$ 115.

East, R.; Kain, W.M. 1982. Prediction of grass grub, Costelytra zealandica, (Coleoptera: scarabaeidae) populations. New Zealand Entomologist 7: 222-227.

Eerens, J.P.J.; Hardwick, S. 2003. Factors affecting clover root weevil (Sitona lepidus) numbers and clover production. New Zealand Journal of Agricultural Research 46: 305-310.

Farrell, J.A.K.; Sweney, W.J. 1972. Plant resistance to the grass grub, Costelytra zealandica (Col. Scarabaeidae). New Zealand Journal of Agricultural Research 15: 904-908.

Ferguson, C.M.; McNeill, M.R.; Phillips, C.B.; Hardwick, S.; Barton, D.M.; Kean, J.M. 2012. Status of clover root weevil and its biocontrol agent in the South Island after six years. Proceedings of the New Zealand Grassland Association 74: 171176.

Fraser, T.J. 1994. Persistence of dryland pasture species in mixed swards in Canterbury. Proceedings of the New Zealand Grasslands Association 56: 77-79. 
Gerard, P.J.; Hackell, D.L.; Bell, N.L. 2007. Impact of clover root weevil Sitona lepidus (Coleoptera: Curculionidae) larvae on herbage yield and species composition in a ryegrass-white clover sward. New Zealand Journal of Agricultural Research 50: 381392.

Gerard, P.J.; Hardwick, S.; Addison, P.J.; Willoughby, B.E.; Goldson, S.L. 2009. The bionomics of an invasive species Sitona lepidus during its establishment in New Zealand. Bulletin of Entomological Research 100: 339-346.

Goldson, S.L. 1979. The reproductive seasonality and reproductive morphology of Argentine stem weevil Hyperodes bonariensis Kuschel (Coleoptera: Curculionidae) and the effect of host grasses on its pre-reproductive development. $\mathrm{PhD}$ thesis, Lincoln College, University of Canterbury.

Goldson, S.L. 1982. An examination of the relationship between Argentine stem weevil (Listronotus bonariensis (Kuschel)) and several of its host grasses. New Zealand Journal of Agricultural Research 25: 395-403.

Goldson, S.L.; Barron M.C.; Kean J.M.; van Koten C. 2011. Argentine stem weevil (Listronotus bonariensis, Coleoptera: Curculionidae) population dynamics in Canterbury, New Zealand dryland pasture. Bulletin of Entomological Research 101: 295-303.

Goldson, S.L.; Bourdôt, G.W.; Proffitt, J.R. 1987. A study of the effects of Sitona discoideus (Coleoptera: Curculionidae) larval feeding on the growth and development of lucerne (Medicago sativa). Journal of Applied Ecology 24: 153-161.

Goldson, S.L.; Dyson, C.B.; Proffitt, J.R.; Frampton, E.R.; Logan, J.A. 1985. The effect of Sitona discoideus Gyllenhal (Coleoptera:Curculionidae) on lucerne yields in New Zealand. Bulletin of Entomological Research 75: 429-442.

Goldson, S.L.; Proffitt, J.R.; McNeill, M.R. 1990. New Zealand seasonal biology and ecology of Microctonus aethiopoides (Hymenoptera: Braconidae), a parasitoid of Sitona spp. (Coleoptera: Curculionidae), with special emphasis on atypical behaviour. Journal of Applied Ecology 27: 703-722.

Goldson, S.L.; Wratten, S.D.; Ferguson, C.M.; Gerard, P.J.; Barratt, B.I.P.; Hardwick, S.; McNeill, M.R.; Phillips, C.B.; Popay, A.J.; Tylianakis, J.M.; Tomasetto, F. 2014. If and when successful classical biological control fails. Biological Control 72: 76-79.

Hardwick, S. 2004. Colonisation of renovated pastures in Waikato by four coleopteran species. New Zealand Plant Protection 57: 304-309.

Jackson, T. 1990. Biological control of grass grub in Canterbury. Proceedings of the New Zealand Grassland Association 52: 217-220.
Jackson, T.A.; Townsend, R.J. 1991. Grass grub damage in irrigated and dryland pastures near Carew, mid Canterbury. Proceedings of the New Zealand Weed and Pest Control Conference 44: 212-213.

Kain, W.M.; Atkinson, D.S. 1977. Development of resistant pasture and methods of pasture management for grass grub (Costelytra zealandica (White)) control. New Zealand Journal of Agricultural Research 20: 507-517.

Kalvelage, H. 1999. Effect of temperature on development of Listronotus bonariensis (Kuschel) (Coleoptera: Curculionidae on Lolium perenne (L.) (Gramineae: Festucoidae). $\mathrm{PhD}$ thesis, Lincoln University.

Knowles, I.M.; Fraser, T.J.; Daly, M.J. 2003. White clover: loss in drought and subsequent recovery. Legumes for dryland pastures. Grassland Research and Practice Series 11: 37-41.

Malone, L.A. 1987. Longevity and fecundity of Argentine stem weevils, Listronotus bonariensis (Coleoptera: Curculionidae), infected with Microsporidium itiiti (Protozoa: Microspora). Journal of Invertebrate Pathology 50: 113-117.

McNeill, M.R.; Goldson, S.L.; Proffitt, J.P.; Phillips, C.B.; Addison, P.J. 2002. A description of the commercial rearing and distribution of Microctonus hyperodae (Hymenoptera: Braconidae) for biological control of Listronotus bonariensis (Kuschel) (Coleoptera: Curculionidae). Biological Control 24: 167-175.

McNeill, M.R.; Proffitt, J.R.; Barlow, N.D.; Goldson, S.L. 2003. Population regulation of Argentine stem weevil (Listronotus bonariensis) in dryland Canterbury pastures. Environmental Entomology 32: 771-779.

Mills, A.; Lucas, R.J.; Moot, D.J. 2015. 'MaxClover' grazing experiment: I. Annual yields, botanical composition and growth rates of six dryland pastures over nine years. Grass and Forage Science 70: 557570.

Moot, D.J. 2014. A review of recent research and extension on dryland lucerne in New Zealand. Proceedings of the New Zealand Society of Animal Production 74: 86-93.

Phillips, C.B.; McNeill, M.R.; Hardwick, S.; Vink, C.J.; Kean, J.M.; Bewsell, D.; Ferguson, C.M.; Winder, L.M.; Iline, I.I.; Barron, M.C.; Stuart, B. 2007. Clover root weevil in the South Island: Detection, response and current distribution. New Zealand Plant Protection 60: 209-216.

Prestidge, R.A.; Van Der Zijpp, S.; Badan, D. 1985. Effects of plant species and fertilisers on grass grub larvae, Costelytra zealandica. New Zealand Journal of Agricultural Research 28: 409-417. 
Radcliffe, J.E. 1971. Effects of grass grub (Costelytra zealandica White) larvae on pasture plants. II. Effects of grass grubs and soil moisture on perennial ryegrass and cocksfoot. New Zealand Journal of Agricultural Research 14: 607-617.

Slay, N.W.A.; Brock, J.L. 2002. Tasmanian grass grub: A guide to identification management and control in Hawke's Bay. Hawke's Bay Regional Council. Cliff Press Printers Ltd. 56 pp.

Watson, R.N.; Neville, F.J.; Bell, N.L. 1996. Insect pests associated with white and Caucasian clover in a Bay of Plenty dairy pasture. New Zealand Plant
Protection 49: 234-238.

Watson, R.N.; Neville, F.J.; Bell, N.L.; Harris, S.L. 1997. Caucasian clover for improving summer production in northern regions of New Zealand. Proceedings of the New Zealand Grassland Association 59: 227-232.

Zydenbos, S.M.; Barratt, B.I.P.; Bell, N.L.; Ferguson, C.M.; Gerard, P.J.; McNeill, M.R.; Phillips, C.B.; Townsend, R.J.; Jackson, T.A. 2011. The impact of invertebrate pests on pasture persistence and their interrelationship with biotic and abiotic factors. Pasture Persistence Symposium. Grassland Research and Practice Series 15: 109-118. 